\title{
A STUDY OF CORPORATE SOCIAL RESPONSIBILITY PRACTICES AND ITS EFFECT ON SOCIETY
}

\author{
Masood Khan \\ Research Scholar, Department of management Studies, \\ Vivekananda Global University, Jaipur, Rajasthan, India \\ Dr. Manisha Choudhary \\ Associate Professor, Department of management Studies, \\ Vivekananda Global University, Jaipur, Rajasthan, India
}

\begin{abstract}
The philosophy of CSR has been a great debatable topic for researchers, CSRExperts, practitioners, businesses, public or private entities, and academics for almost decades since the 1950s, but CSR standard definition remains vague due to its expended approaches to this field. Nowadays, every firm around the globe considers and pays careful attention to their social responsibilities. Before the 1960s, companies had to focus on daily business operations and envisioned only benefits but currently, strategies of organizations are experienced differently as compared to the earliest businesses. The focus of the research paper imparts corporate social responsibility practices by Afghan GSM companies i.e. AWCC, Roshan, Etisalat, MTN, Afghan Telecom and Wasel Telecom and their impact on society key areas such as education, health, sports, and community relationship and environmental relationship. Furthermore, this study strives to suggest a CSR model relating to CSR activities that could be included in the firm's main objectives with specific reference to the Afghan telecom sector. Also, this paper briefly explains, definitions of terms related to study and social responsibility historical details.
\end{abstract}

Key words: AWCC, CSR, Service, MTN, Afghan Telecom.

Cite this Article: Masood Khan and Manisha Choudhary, A Study of Corporate Social Responsibility Practices and Its Effect on Society, International Journal of Management (IJM), 11(12), 2020, pp. 3194-3201.

http://iaeme.com/Home/issue/IJM?Volume $=11 \&$ Issue $=12$

\section{INTRODUCTION}

The term "Corporate Social Responsibility" or simply CSR has a deep history, justifying its activities impact on organizational performance and thus its influence on society. The 
philosophy of CSR has been a great debatable topic for researchers, CSR-Experts, practitioners, businesses, public or private entities, and academics for almost decades since the 1950s, but CSR standard definition remains vague due to its expended approaches to this field. Nowadays, every firm around the globe considers and pays careful attention to their social responsibilities. Before the 1960s, companies had to focus on daily business operations and envisioned only benefits but currently, strategies of organizations are experienced differently as compared to the earliest businesses. They intend to care, be supportive, and responsive in the societies they operate, thus social practitioners seems these actions a voluntary contribution to the community. (Carroll 1979). Nearly most organization in the world with regards to their economic capacity and business volume confirms and considers themselves a responsible citizen of the community and environment. Organizations seek and strive to create a stronger relationship in society for their sustainable profit and survival. They aim to build trust and the ability to attract more customers to the market. Communities are the main target and important segment for any business therefore, enterprises must be honest to creating a stronger, stable, friendly, and social business environment.

CSR is taken by firms as a multi-profit tool, creating a healthier image in the market that promotes company reputation and reliability with stakeholders. Social Responsibilities build co-relation among society and business and bring them together and closer to each other, so the business is bound to become more socially responsible, being more thoughtful and responsive to community and environment. Additionally, CSR could be a great source for a firm's competitive advantage (Masood, Pankaj 2019).

CSR's goal is to treat every interested party on a balanced scale because these activities directly impact employees, corporations, customers, and the community. The focus of the research paper imparts corporate social responsibility practices by Afghan GSM companies i.e. AWCC, Roshan, Etisalat, MTN, Afghan Telecom and Wasel Telecom and their impact on society key areas such as education, health, sports, and community relationship and environmental relationship. Furthermore, this study strives to suggest a CSR model relating to CSR activities that could be included in the firm's main objectives with specific reference to the Afghan telecom sector. Also, this paper briefly explains, definitions of terms related to study and social responsibility historical details.

\section{OBJECTIVES OF THE STUDY}

The main objective of the study is to study and evaluate the CSR activities of the cellular phone companies in Afghanistan. A model is proposed for Afghan private firms. More specifically the objectives are i.e.

- To understand the nature of CSR practices in the telecommunication sector in Afghanistan.

- To examine the effect of CSR on society in Afghanistan.

- To suggest a model of CSR for Afghan private firms.

\section{REVIEW OF LITERATURE}

One of the simplest ways of economizing effect in an inquiry is to review and build upon the work already done by others. A comprehensive review of literature is done under the research with thorough consideration and efforts have been made on the part of the researcher to select a review to arrange it systematically and report it. An in-depth review of literature facilitates knowing the trend of research already done in a specific area.

The review understudy relates to the CSR practices in telecom sector in Afghanistan, with an emphasis on its impact on society. The review describes CSR policies and practices in 
telecom sector. It also summarizes available evidence from previous reviews of corporate social responsibility and its practice to identify factors that contribute to the success or failure of corporate social responsibility practices. The focus of the review is to summarize, organizes, and analyze the existing descriptive and analytical material in the literature. Literature reviews offer insights into the theoretical and conceptual base of CSR.

The review provides theoretical literature on CSR activities in the private telecom sector and literature on studies that explore the relation among CSR initiatives and the stakeholders.

\section{CSR THEORIES}

Several changes might happen to businesses with the passage of time due to culture, demand, taste, time duration, society, customers, and situation. All these variations have been emerged with social and environmental issues due to the above-mentioned factors. The traditional concept of business was used to make more money but nowadays, business ethics are considered more important than profit.

Researchers found that Business Ethics turns to profit sustainability at a long turn. Similarly, CSR and its impact on society and business have been changed throughout history. CSR theories have been developed since 1950s-1990s (CSR origination- Carroll 1960) and are continued proclaiming their value in the business world till today. Before 2000, these theories were brought to bring social awareness and ethical behaviors among businesses and societies. Social accountability came more practical after 2000s. As regions same as CSR theories adoption and implementation is differently practiced, CSR by developed nations like the United States and European countries - has been defined as a philanthropic process in late decades where companies were sharing their part of the profit to the charitable organizations helping poor communities. While European firms intend to focus more on society, having said that the European organizations were operating in diverse ethical ways considering their internal and external customers.

There are certain CSR theories in social sciences proposed by business experts and scholars, but few ones still exist with higher intention in the market. This study will put light on known CSR theories which are acceptable and common in the literature. Following CSR theories are described by the researcher, which are appropriate for this study and will help other businesses and scholars.

- Friedman Theory (Shareholder Theory)

- Freeman theory (Stakeholder Theory

- Triple Bottom Line Theory

- Agency Theory

- Resource Based View theory (RBV Theory)

\section{MODELS OF CSR}

Earlier during the traditional time, businesses were intended to make a profit and respond to consumer's demand by producing qualitative products and services. Due to modern industrialization and stakeholder's interest, it came to know that a company should have an equilibrium taking business decisions treating all attached parties for its survival. Purposively, academicians proposed many diverse business concepts for social responsibilities of firms, as CSR- which aims to keep a firm social, environmentally friendly and ethically responsible to each internal and external stakeholder. CSR has been debated vaguely by different viewers concerning cultural, religious, population, and race differentiation. 
Many works of the literature demonstrated and focused on the economic model of CSR. Carroll's CSR model is well known in social sciences and cited more than any other typical scheme in the field; it has four main elements which talk about the legal, social, environmental, and economic responsibilities of an organization. There are three basic and most prominent CSR models in the social and ethical subjects.

- Carroll's CSR pyramid

- CSR Intersecting Model

- CSR Centric Model

\section{CSR IN EUROPEAN COUNTRIES}

Public jurisdiction as EU in Europe plays a critical role in assisting firms, supporting them legislatively, direct them to perform business operations in an efficient way. A report on CSR, Responsible Business Conduct (RBC), and Business-Human Rights published by European Commission (EC)-Brussels in 2019 clearly defines the social responsibility of European firms in a concise manner. EC has an emergence role to promote CSR under Guiding Principles on Business and Human Rights of United Nations (UNGPs).

United Kingdom (UK) has been considered as lead CSR country in the region, due to its universal position and rich history. As per Capital Care Report (UK), 3/4 individuals agree that their organizations should go beyond legal compliance for environmental protections and $1 / 2$ believe to support local communities. There are several legal rules encompassed by UK government to be implemented by firms to serve society and environment.

\section{CSR IN UNITED STATES OF AMERICA (USA)}

CSR in the USA has been originated in 1970s during the "social contract" among businesses and communities which was proposed by Committee for Economic Development. It has been practiced by US in the areas of humanitarianism, charity, environmental conservation and volunteerism. CSR is not treated as a mandate legal issue in the US. Businesses are asked to engage in social and environmental volunteer practices and these practices are defined as Admirable actions (Fifka, 2013). A study by Brammer in 2005 shows that US corporations

contribute ten times more as compared to British firms. However, USA is consuming an average of $207 \%$ of ecological capacity as per World Watch 2015 reports. Corporate responsibilities and environmental concerns in society are the errands of the government to be considered. (Camilleri, 2015). Therefore, larger firms in US are asked to engage in CSR because these firms are leading drivers for economic sustainability.

\section{CSR IN AFRICA}

Social Responsibility has been recognized in different contexts in the world. CSR in Africa have been copied mostly from Western world (Dobers 2009). But most studies in Africa shows that Western social theories could not be fully applicable in African context.

Africa has been considered the second-largest moderate territory in the world in accordance with the population which reaches nearly to almost one billion people. Africa's economy has been spontaneously growing in late decades. CSR arguments in Africa are being elevated by experts and academics interestingly (Okoye 2005). The export of commodities to international markets is at a low level due to weak trade, economics, and market constancy (George, Forstater 2010). There are developmental challenges in Africa that are seriously considered, a big chunk of the percentage earns USD two per day or maybe less. The challenges in the region are poverty, basic education, gender concerns, women empowerment, child abuse, lack of health facilities, and environmental considerations (Source: CSR papers and publications). 


\section{CSR IN INDIA}

India is assumed to be the initial CSR legislative country in the world. India CSR act 2013, stated that a business firm should compliance its social activities in key areas such as equal gender opportunities, education, and eliminating poverty-hunger reducing. This act instructed all companies to invest their $2 \%$ of total profit every year (Dezan Shira July 2013). This act has been derived from Mahatma Gandhi's CSR model which is still known as the "Trusteeship Model" (Harijan).

\section{CSR PRACTICES IN AFGHANISTAN}

The Karzai Administration of Afghanistan has encouraged larger firms or multinational companies to invest in CSR. There are few national and international companies involved in philanthropic activities such as Beverage Firms, Financial Institutions and Mobile Telecommunication. A report published by Export.gov (https://www.trade.gov/exportsolutions) stated that the mining sector has been involved to protect the society and environment of the hazardous weapons, battlefield fragments, or metal items that have been retained in the soil. Some GSM companies developed and implemented social outreach programs in the region including health, education, sports, infrastructure social development, and many more.

\section{PROBLEM STATEMENT}

Most of the CSR debate is being discussed from earlier stages of Friedman's Shareholder theory (1970) and Freeman's Stakeholder theory (1984). For the time being, discussions have made huge progress towards the influence of CSR on businesses and societies. CSR should be considered as a volunteer commitment by both private and public organizations. They should be socially responsible for their activities in the corporate world, and in reality, it is very complex to define CSR empirical meaning by firms. Experts and practitioners have clearly defined the benefits of CSR and its impact on society (Swaen, 2008). Afghanistan is a war-torn country, has remained too away from global relations and business affinities for decades from the business world. In reality, Government is the primary authority that is responsible to provide social assistance to the public but the impact of the past and ongoing civil conflicts, lack of better management, ethical and religious disparities, poor economy, and most probably high threat security issues in Afghanistan are the main obstacles for the sustainable economic development of the country. This study focuses on Corporate Social Responsibility definitions, CSR activities performed by selected firms in Afghanistan, CSR principles. In addition, it emphasizes checking the impact of social accountabilities performed by companies on society. The research also focuses to propose at developing a CSR common model for private firms in Afghanistan.

\section{CONCLUSION}

Many businesspeople believed that CSR outlook is only related to a firm's profit but due to the high demand for CSR and interesting debates among many scholars, practitioners, and researchers, the traditional trend turned businesses to a new social and environmental ideology of CSR. This study represents the notions of internal employees of selected firms for the research and external stakeholders of the society including CSR beneficiaries, customers, government authorities, etc. The researcher observed four firms' social practices implemented by them as of 2019 and distinguished them into two major categories including Internal/external areas of firms' discretionary efforts. Internal CSR areas cover Employee Relations. CSR in Afghanistan is not practiced at a fair proportion as expected to be done, as earlier mentioned, there are few corporations particularly in telecom sector, which performed more social tasks as compared to any other division of the industry. Furthermore, these CSR practices have been 
implemented in an unorganized and traditional way. It is noticed that selected firms for this study have their own mechanisms of practicing their CSR programs. It is very important to have common and standard models of CSR or a roadmap of social implementation for firms in Afghanistan. During the study, it was found that almost all companies have a merged department of CSR engaged or/and with Legal Department of that firm.

To get in conclusion, CSR must be integrated into a firm's strategy. This ideology should be accepted as a survivance model by businesses. Moreover, CSR does not mean to earn profit only but to consider giving back to society. Mahatma Gandhi declared social responsibilities as an ethical act for business firms. A company should maintain to conduct its business ethically and ask its personnel to behave in a well-mannered professional fashion.

\section{SUGGESTED CSR MODEL FOR AFGHAN PRIVATE FIRMS}

Below suggested model of CSR justifies the third recommended objective of the study which is "To propose a CSR model of private firms in Afghanistan" This figure presents CSR model concerning local Afghan firms. The model contains internal and external stakeholders who are associated with the firm. It intends to derive advantages by applying CSR. The hierarchical process of CSR implementation clarifies the whole scenario of social responsibilities which enhance and lead to organizational performance. Below is a detailed explanation of the figure.

\section{CSR Suggested Model}

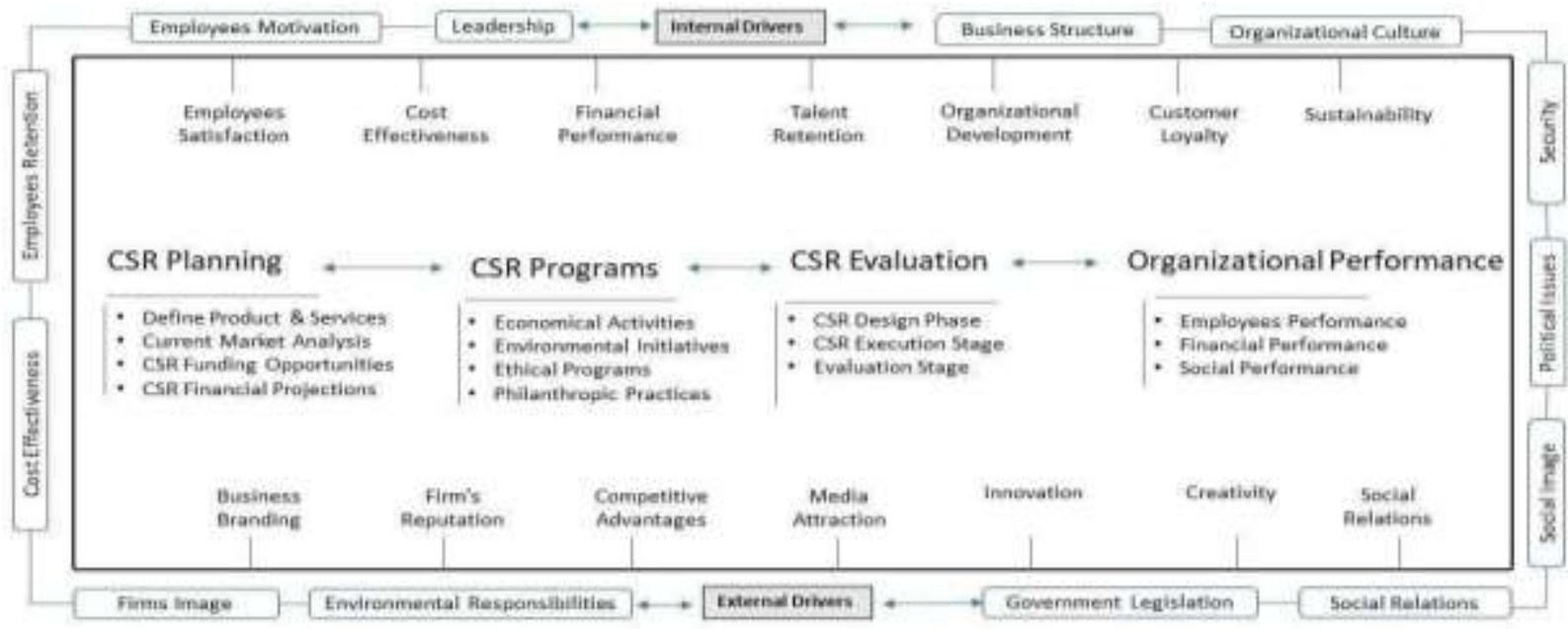

Figure 1

Any business activity such as consultancy, production, commercial and noncommercial trade, construction, engineering, transportation, health, sports, and quality assurance should be performed by corporates in an acceptable approach which results in trust, achieving the satisfaction of customers through fulfilling demands of each stakeholder and the long term relations in the society. Such firms would be able to consider stakeholders as loyal firms to their social commitments.

Overall, social activities are accepted as important business strategies of firms and intend to impact the internal firm's environment and external society.

\section{REFERENCES}

[1] Annales University Apulensis Series Oeconomica, (17, 2015), 31-48 History of "Corporate Social Responsibility" Concept 
[2] Ahmad Azizi, Sameer, (July 2015) CSR in Afghanistan.

[3] Agyei, M, J. (2014). Relationship between Corporate Image and Customer Loyalty in the Mobile Telecom in Kenya. Management Studies, 2-5.

[4] Aaker, D. (1996). Measuring brand equity across products and markets. California Management Review, 38-3,102, 20.

[5] Abdullah, Z., \& Aziz, J. (2013). Institutionalizing CSR: Malaysia. Social Responsibility Journal, 9-3, 354-361.

[6] Adhikari, A. D. (2012). Status of CSR in Nepal. Journal 12 (5), $642-655$.

[7] AMA. (2010), Annual Report on American Marketing Association.

[8] Bhanu Mati Doshi and Hitesh Tikyani, A Theoretical Integration of GIG Economy: Advancing Opportunity, Challenges and Growth, International Journal of Management (IJM), 11(12), 2020, pp. 3013-3019.

[9] Bergkamp L, (2002). Corporate Governance and Social Responsibility:

[10] Biel A.L. (1993). How Brand Image Drives Brand Equity. Journal of Advertising Research.

[11] Carroll (Archie), (1979). Three-dimensional theoretical model of corporate performance (CP).

[12] Carroll, A. B. (1991). The pyramid of social responsibilities: Business Horizons, 34-4), 39-48.

[13] Committee for Economic Development (CED), (1971). Social responsibilities of business corporations (SRBR). New York: CED.

[14] Carroll, (2000). Ethical challenges for corporates in the new millennium: Social responsibilities and models. Business Ethics Quarterly, 10-1, 35.

[15] Corporate Social Responsibility; Importance, Benefits, Consequences, Approaches to Managing CSR Ng Wee Yee B0900623

[16] Chang \& Liu. (2014). Customer Commitment as a Mediating Variable between Corporate Brand Image (CBI) and Customer Loyalty (CL).

[17] Hess, D (2008). The meaning and meaningfulness of corporate social initiatives.

[18] Isabelle Malignant, (2010), Corporate Social Responsibility in Europe and the U.S.

[19] Jamali and Karam, (2010). CSR in Developed and Developing Countries.

[20] Jia and Zhang (2014). How does the stock market value corporate social performance (CSP)?

[21] Jamali, D. (2008). A stakeholder approach CSR: A fresh perspective into theory and practice.

[22] Manisha Choudhary and Saroj Kumar Ranjan, Work Stress and Burnout: Eustress A Tool to Deal, International Journal of Management (IJM), 11(12), 2020, pp. 3142-3147.

[23] Rawat pooja, doshi bhanu and Ranjan Saroj (2021) Development of small \& medium scale enterprises: protagonist of commercial banks funding. 
[24] Siltaoja, (2005). Value priorities as combining core factors between social activities and reputation.

[25] Sailaja, (2006). Value priorities as combining core factors between CSR and Corporates Reputation.

[26] Spence, A. (1974). Market Signaling: Informational in Hiring and Screening Procedures.

[27] Towseef Ahmad, (2014), CSR: A National and International Perspective, University of Kashmir, Srinagar, India

[28] Theuws, M.2013 CSR: A Comparison of the OECD Guidelines, ISO 26000 \& the UN.

[29] Windsor, (2001). The future of CSR. International Journal of Organizational Analysis.

[30] Wang, (2014). Impact of CSR on Brand Image.

[31] Xu, Y. (2007). Impact of Store environment on Adult generation.

[32] Yoo, \& Park, (2007). Perceived service quality (Analyzing relationships among employees, customers, and financial performance.

[33] Zeittey \& Kaman, (2015), Corporate Social Responsibility (CSR) Models: An Approach to Environmental Perspective. 